\title{
Front Matter: Volume 11245
}

, "Front Matter: Volume 11245," Proc. SPIE 11245, Three-Dimensional and Multidimensional Microscopy: Image Acquisition and Processing XXVII, 1124501 (13 March 2020); doi: 10.1117/12.2566019

SPIE. Event: SPIE BiOS, 2020, San Francisco, California, United States 


\title{
Three-Dimensional and Multidimensional Microscopy: Image Acquisition and Processing XXVII
}

\author{
Thomas G. Brown \\ Tony Wilson \\ Laura Waller \\ Editors
}

3-5 February 2020

San Francisco, California, United States

Sponsored and Published by

SPIE 
The papers in this volume were part of the technical conference cited on the cover and title page. Papers were selected and subject to review by the editors and conference program committee. Some conference presentations may not be available for publication. Additional papers and presentation recordings may be available online in the SPIE Digital Library at SPIEDigitalLibrary.org.

The papers reflect the work and thoughts of the authors and are published herein as submitted. The publisher is not responsible for the validity of the information or for any outcomes resulting from reliance thereon.

Please use the following format to cite material from these proceedings:

Author(s), "Title of Paper," in Three-Dimensional and Multidimensional Microscopy: Image Acquisition and Processing XXVII, edited by Thomas G. Brown, Tony Wilson, Laura Waller, Proceedings of SPIE Vol. 11245 (SPIE, Bellingham, WA, 2020) Seven-digit Article CID Number.

ISSN: 1605-7422

ISSN: 2410-9045 (electronic)

ISBN: 9781510632530

ISBN: 9781510632547 (electronic)

Published by

SPIE

P.O. Box 10, Bellingham, Washington 98227-0010 USA

Telephone +1 3606763290 (Pacific Time) · Fax +1 3606471445

SPIE.org

Copyright (c) 2020, Society of Photo-Optical Instrumentation Engineers.

Copying of material in this book for internal or personal use, or for the internal or personal use of specific clients, beyond the fair use provisions granted by the U.S. Copyright Law is authorized by SPIE subject to payment of copying fees. The Transactional Reporting Service base fee for this volume is $\$ 21.00$ per article (or portion thereof), which should be paid directly to the Copyright Clearance Center (CCC), 222 Rosewood Drive, Danvers, MA 01923. Payment may also be made electronically through CCC Online at copyright.com. Other copying for republication, resale, advertising or promotion, or any form of systematic or multiple reproduction of any material in this book is prohibited except with permission in writing from the publisher. The CCC fee code is 1605$7422 / 20 / \$ 21.00$.

Printed in the United States of America by Curran Associates, Inc., under license from SPIE.

Publication of record for individual papers is online in the SPIE Digital Library.

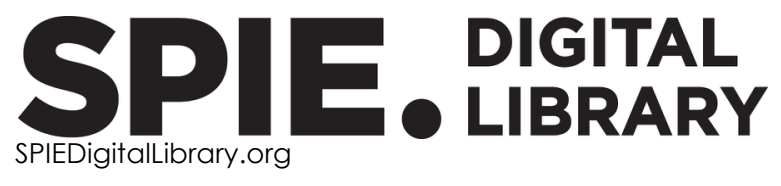

Paper Numbering: Proceedings of SPIE follow an e-First publication model. A unique citation identifier (CID) number is assigned to each article at the time of publication. Utilization of CIDs allows articles to be fully citable as soon as they are published online, and connects the same identifier to all online and print versions of the publication. SPIE uses a seven-digit CID article numbering system structured as follows:

- The first five digits correspond to the SPIE volume number.

- The last two digits indicate publication order within the volume using a Base 36 numbering system employing both numerals and letters. These two-number sets start with 00, 01, 02, 03, 04, $05,06,07,08,09,0 A, 0 B \ldots$ OZ, followed by 10-1Z, 20-2Z, etc. The CID Number appears on each page of the manuscript. 


\title{
Contents
}

\author{
$\checkmark \quad$ Authors \\ vii Conference Committee
}

QUANTITATIVE PHASE AND HOLOGRAPHIC IMAGING

1124503 3D refractive index tomography with quantitative oblique back-illumination microscopy [11245-2]

SINGLE PLANE ILLUMINATION AND LIGHT SHEET MICROSCOPY

11245 ol Multi-immersion open-top light-sheet microscopy (Invited Paper) [1 1245-16]

COMPUTATIONAL IMAGING

1124500 Computational super-resolution microscopy: leveraging noise model, regularization and sparsity to achieve highest resolution [1 1245-21]

11245 OR Wavelet-based characterization of the spatial relationship of nerve and collagen in neuropathic adipose tissue [11245-24]

EXTENDED DEPTH OF FOCUS MICROSCOPY

11245 ОT Multifocus imaging via polarization wavefront shaping [1 1245-26]

11245 OU A study for accelerating the speed of all-in-focus image processing [11245-27]

INNOVATIVE METHODS IN MICROSCOPY

11245 OY Excitation-scan mirror array system advancements to hyperspectral imaging applications [11245-31]

1124510 Three-dimensional tomographic imaging and quantitative phase measurement using virtual phase conjugation [1 1245-33] 
1124512 A multiplexed confocal FLIM microscope with 4-taps time-gated imager [11245-35]

$1124514 \quad 3,3^{\prime}$-thiodipropanol as a refractive index matching mounting medium for fluorescence microscopy [11245-37]

1124515 Super-speed multiphoton microscopy for mesoscopic volume imaging with ultra-dense sampling beyond Nyquist Limit [11245-38]

\section{POSTER SESSION}

$1124517 \quad$ FPGA implementation of spectral fusing Gabor domain optical coherence microscopy [11245-40]

1124518 Evaluation of a combined two-color phase plate forming three-dimensional dark holes in super resolution microscopy [11245-41] 


\section{Authors}

Numbers in the index correspond to the last two digits of the seven-digit citation identifier (CID) article numbering system used in Proceedings of SPIE. The first five digits reflect the volume number. Base 36 numbering is employed for the last two digits and indicates the order of articles within the volume. Numbers start with 00, 01, 02, 03, 04, 05, 06, 07, 08, 09, 0A, 0B...0Z, followed by 10-1Z, 20-2Z, etc.

Alata Tejedo, Milvia Iris, 14

Badr, Fares, 12

Becker, Stephen, 00

Bokor, Nándor, 18

Borah, Bhaskar Jyoti, 15

Browning, Craig M., OY

Chen, Simeng, 00

Chi, Han-Hsiung, 15

Cogswell, Carol, 00

Deal, Joshua, OY

Ding, Changqin, OT

Fang, Qiyin, 12

Glaser, Adam K., Ol

Gunn-Mayes, Samantha, OY

Harling, Mitchell, OR

Hayashi, Naoki, 10

Iketaki, Yoshinori, 18

Ishikawa, Masatoshi, oU

Johnson, Cory P., OR

Juybari, Jeremy, OR

Kagawa, Keiichiro, 12

Kawahito, Shoji, 12

Kawashima, Satoshi, 10

Khalil, Andre, OR

Kodaira, Akira, 18

Kumagai, Hiroshi, 18

Leavesley, Silas J., OY

Ledwig, Patrick B., 03

Lenaphet, Yutana, 17

Li, Chen, OT

Li, Minghe, OT

Liu, Jonathan T. C., Ol

Maeda, Tomohiro, 10

Martinez Cervantes, Juan Carlos, 14

Maruyama, Takashi, 18

Mayes, Sam A., OY

Meemon, Panomsak, 17

Nagai, Koumei, 18

Ogawa, Kazuhisa, 10

Okamoto, Atsushi, 10

Osaki, Ryusuke, 10

Parker, Marina, OY

Piazza, Valeria, 14

Rich, Thomas C., OY

Richards, Morgan, 12

Robles, Francisco E., 03

Rong, Jiayue, OT

Saetiew, Jadsada, 17

Shirakawa, Yuya, 12

\author{
Simpson, Garth J., OT \\ Sun, Chi-Kuang, 15 \\ Tabata, Satoshi, OU \\ Takeuchi, Hirotoshi, oU \\ Tilbury, Karissa, OR \\ Tomita, Akihisa, 10 \\ Townsend, Kristy L., OR \\ Ulcickas, James, OT \\ Wang, Lihui, OU \\ Xing, Jian, 00 \\ Yen, Chen-Tung, 15 \\ Yu, Jiun-Yann, 00
}


Proc. of SPIE Vol. 11245 1124501-6

Downloaded From: https://www.spiedigitallibrary.org/conference-proceedings-of-spie on 26 Apr 2023 Terms of Use: https://www.spiedigitallibrary.org/terms-of-use 


\title{
Conference Committee
}

\author{
Symposium Chairs
}

Jennifer K. Barton, The University of Arizona (United States)

Wolfgang Drexler, Medizinische Universität Wien (Austria)

Program Track Chairs

Ammasi Periasamy, University of Virginia (United States)

Daniel L. Farkas, University of Southern California (United States) and SMI (United States)

Conference Chairs

Thomas G. Brown, University of Rochester (United States)

Tony Wilson, University of Oxford (United Kingdom)

Laura Waller, University of California, Berkeley (United States)

\section{Conference Program Committee}

Martin Booth, University of Oxford (United Kingdom)

Charles A. DiMarzio, Northeastern University (United States)

Jonathan T.C. Liu, University of Washington (United States)

Raimund J. Ober, Texas A\&M University (United States)

Chrysanthe Preza, The University of Memphis (United States)

Monika Ritsch-Marte, Medizinische Universität Innsbruck (Austria)

Zachary J. Smith, University of Science and Technology of China (China)

\section{Session Chairs}

1 Quantitative Phase and Holographic Imaging

Martin J. Booth, University of Oxford (United Kingdom)

2 Illumination and Optical Coherence

Thomas G. Brown, The Institute of Optics, University of Rochester (United States)

3 Multidimensional Image Reconstruction and Analysis

Adam K. Glaser, University of Washington (United States)

4 Single Plane Illumination and Light Sheet Microscopy

Charles A. DiMarzio, Northeastern University (United States) 
5 Computational Imaging

Zachary J. Smith, University of Science and Technology of China (China)

6 Extended Depth of Focus Microscopy

Raimund J. Ober, Texas A\&M University (United States)

7 Innovative Methods in Microscopy

Jonathan T. C. Liu, University of Washington (United States)

8 Fluorescence and Nonlinear Microscopy

Thomas G. Brown, The Institute of Optics, University of Rochester (United States) 